\title{
MUSCULAR DYSTROPHY AND RELATED DISORDERS
}

\author{
Victor Dubowitz, B.Sc., M.D., M.R.C.P., D.C.H. \\ Lecturer in Child Health, University of Sheffield.
}

THE TERM muscular dystrophy is reserved for those cases of progressive weakness of skeletal muscle which are genetically determined and in which the primary pathological change is in the muscle itself and is not secondary to disease of the central or peripheral nervous system.

\section{Classification}

Various types of muscular dystrophy are recognised on the basis of different clinical patterns and different modes of inheritance. The pathological changes in the muscle are similar in character in the different types, but may vary considerably in severity.

The various myotonic syndromes are usually also included under the broad definition of muscular dystrophies, but differ from the 'pure' muscular dystrophies in a number of respects.

\section{Historical}

Adolescent and adult forms of progressive muscular paralysis were already recognised by Darwell (1830), Bell (1830) and Aran (1850), but these early authors did not distinguish those forms of muscular atrophy secondary to diseases of the nervous system.

The childhood form of muscular dystrophy is usually associated with the name of Duchenne, who gave a detailed single case report in 1861 and a masterly description of the disease, based on 13 cases, in 1868 . He coined the term "pseudohypertrophic" to describe the unusual enlargement of muscles, which were nevertheless abnormal and weak. Duchenne, however, was not the first to describe the disease. Coste and Gioja (1838) recorded two brothers with progressive weakness of the legs, associated with prominent calves, and in 1852 Meryon described nine cases and also commented on the enlargement of the calf muscles. The beautifully lucid writings of Gowers (1879) on 'pseudohypertrophic paralysis' are still well worth reading. I do not think any subsequent writer has improved $\overrightarrow{\mathrm{a}}$ his vivid descriptions.

In 1876, Leyden described a less sevege atrophic form of muscular weakness affectirg the pelvic girdle. Möbius (1879) commented on certain points of similarity between this type and Duchenne's pseudohypertrophid paralysis. Their reports form the basis of the so-called atrophic pelvi-femoral variety of muscular dystrophy (limb girdle).

In 1884 Landouzy and Déjerine drew atteo tion to the progressive atrophy affecting the scapulo-humeral muscles and associated with weakness of the facial muscles. In some cases the facial weakness presented in early child. hood as the first manifestation of the diseases in others it appeared only later. This form of muscular dystrophy, the facio-scapulo humerir variety, still bears the names of Landouzy an Déjerine, although nine similar cases ha⿳亠 already been published by Duchenne in $187 \%$ It is probably as well, though, that Duchenness name is only attached to one type.

Erb $(1884,1891)$ described a juvenile for of progressive muscular atrophy with onset childhood or adolescence. The muscles of the back, shoulders and upper arms were usually more affected, but some cases showed mope marked involvement of the pelvic girdle and lower limbs. In the course of his very voluminous writings, most of which weee devoted, without trace of modesty, to the eulogy of Erb, he reviewed the various fornis of progressive muscular atrophy without neuris logical involvement, and proposed the term "dystrophia muscularis progressiva" to cover the whole group. The name of Erb is still associated with the scapulo-humeral variety of muscular dystrophy.

Although Meryon, Duchenne, Gower, Landouzy and Dejerine and Erb had all noted already the tendency to a familial incidenge of muscular dystrophy it was not until many years later that attempts were made to corre late specific patterns of inheritance with variouss 
clinical types (Weitz, 1921; Diehl, Hansen and V. Ubisch, 1937; Minkowski and Sidler, 1928; Davidenkow, 1930; Sjövall, 1936; Bell, 1943).

Milhorat and Wolff (1943) attempted to dispense with all forms of subdivision and grouped all muscular dystrophies together irrespective of clinical or genetic variation. Tyler and Wintrobe (1950) tried to divide all cases into only two types, viz. childhood type (including the Duchenne pseudotrophic and the Leyden-Möbius atrophic pelvi-femoral types) and the facio-scapulo-humeral variety.

\section{Modern Classifications}

In the 1950's a more practical clinical approach was once more established, recognising the various clinical patterns of the early authors, and also applying the advances in genetic knowledge.

Levison (1951) suggested:-

1. Scapulo-humeral type (Erb)

2. Facio-scapulo-humeral type (Landouzy and Déjerine)

3. Lower extremity type (Duchenne and Leyden-Möbius)

Stevenson (1953), on the basis of clinical and genetic studies recommended:-

1. Duchenne-type rapidly progressive muscular dystrophy of young boys (sex-linked)

2. Autosomal limb girdle type

(a) with facial involvement.

(b) without facial involvement.

Becker (1953) divided his cases into a shoulder girdle or descending form, and a pelvic girdle or ascending form. He subsequently (Becker, 1957) subdivided the pelvic girdle group into a malignant and $a$ benign $X$ chromosomal (sex-linked) type and an autosomal recessive type.

Walton and Nattrass (1954), on the basis of extensive clinical and genetic studies, concluded that Stevenson's criteria for the Duchenne type were too rigid. They also preferred to separate the facio-scapulo-humeral from the scapulohumeral varieties. Their suggested classification was:

1. Duchenne type (including childhood pelvi-femoral type) (sex-linked recessive inheritance).

2. Facio - scapulo-humeral. (autosomal dominant)

3. Limb girdle (starting in either shoulder or the pelvic girdle) (autosomal recessive).

Blyth and Pugh (1959) made a genetic study of muscular dystrophy in childhood and sub- divided their cases into a severe group who were off their feet by the age of 11, and a mild group who were still ambulant after that age. All cases in the severe group conformed to a sex-linked pattern of inheritance, while the mild group contained sex-linked recessive, autosomal recessive and occasionally autosomal dominant cases. This form of subdivision into severe and mild cases on the basis of ambulation till an arbitary age may break down when one finds broihers falling on either side of the dividing line (Dubowitz, 1960).

While the classification of Walton and Nattrass (1954) has proved a useful basis for clinical subdivision and has been generally accepted, difficulties have arisen because of the overlap of clinical types. Thus from a genetic viewpoint, there can be no doubt that a severe form of muscular dystrophy, clinically indistinguishable from the Duchenne type, can be inherited as an autosomal recessive (Dubowitz, 1960). Chung and Morton (1959) and Morton, Chung and Peters (1963) prefer to classify these severe autosomal recessive cases with the milder autosomal recessive limbgirdle type and to reserve the Duchenne type for sex-linked cases only. These authors also note that some cases of limb-girdle dystrophy appear to be truly sporadic and not autosomal recessive. While some of these sporadic cases may be due to occasional penetrance in the heterozygous carriers of recessive genes for dystrophy, this group may well embrace some of the metabolic and acquired myopathies which can present in a similar manner.

Becker and Kiener (1955) and Becker (1962) have described families with a sex-linked muscular dystrophy, similar in pattern to the Duchenne type, but much more benign. Some patients were still ambulant 20 years or more after the onset. They look upon this form as genetically distinct from the severe sex-linked Duchenne type.

Taking into account these variations, Walton (1964a) has amended his classification as follows:-

1. Duchenne type muscular dystrophy. Sex-linked recessive variety. Autosomal recessive variety.

2. Limb-girdle muscular dystrophy. Autosomal recessive.

Rarely autosomal dominant or sporadic.

3. Facio-scapulo-humeral muscular dystrophy. Autosomal dominant (rarely recessive). 
Walton does not except Becker's view of a severe and a mild variety of the sex-linked Duchenne form of muscular dystrophy, but looks upon them as variations of one type. He also prefers to classify the severe form of the autosomal recessive variety with the Duchenne group rather than with the limb girdle group as recommended by Morton, Chung and Peters (1963).

It may be argued that the clinical distinction between the severe and mild forms of sexlinked Duchenne type are as great as the distinction between the severe and mild autosomal recessive forms. Under these circumstances I think it would be less confusing to classify these cases either on a genetic or a clinical basis.

The genetic classification would be :-

1. Duchenne Type. Sex-linked recessive. Clinically severe form. Clinically mild form.

2. Limb Girdle Type. Autosomal recessive.

Clinically severe form.

Clinically mild form (occasionally autosomal dominant or truly sporadic).

3. Facio - scapulo - humeral. Autosomal dominant (rarely recessive).

The clinical classification would be:-

1. Duchenne Type. (Pelvic girdle, severe form).

Sex-linked recessive.

Autosomal recessive.

2. Limb Girdle.

(a) Pelvic Girdle (mild form)

Autosomal recessive

Sex-linked recessive

Sporadic

Autosomal dominant

(b) Scapulo-humeral

Autosomal recessive

Sporadic

3. Facio - scapulo - humeral. Autosomal dominant (rarely recessive).

Since in clinical practice one frequently has to deal with an isolated case of muscular dystrophy with a negative family history, I would favour the clinical classification above as a working basis. There is however, no clear dividing line between the Duchenne type and the limb girdle type.

\section{Rare Forms of Muscular Dystrophy}

In addition to the three most common types discussed above, a number of rarer syndromes have been described. The main ones are:-

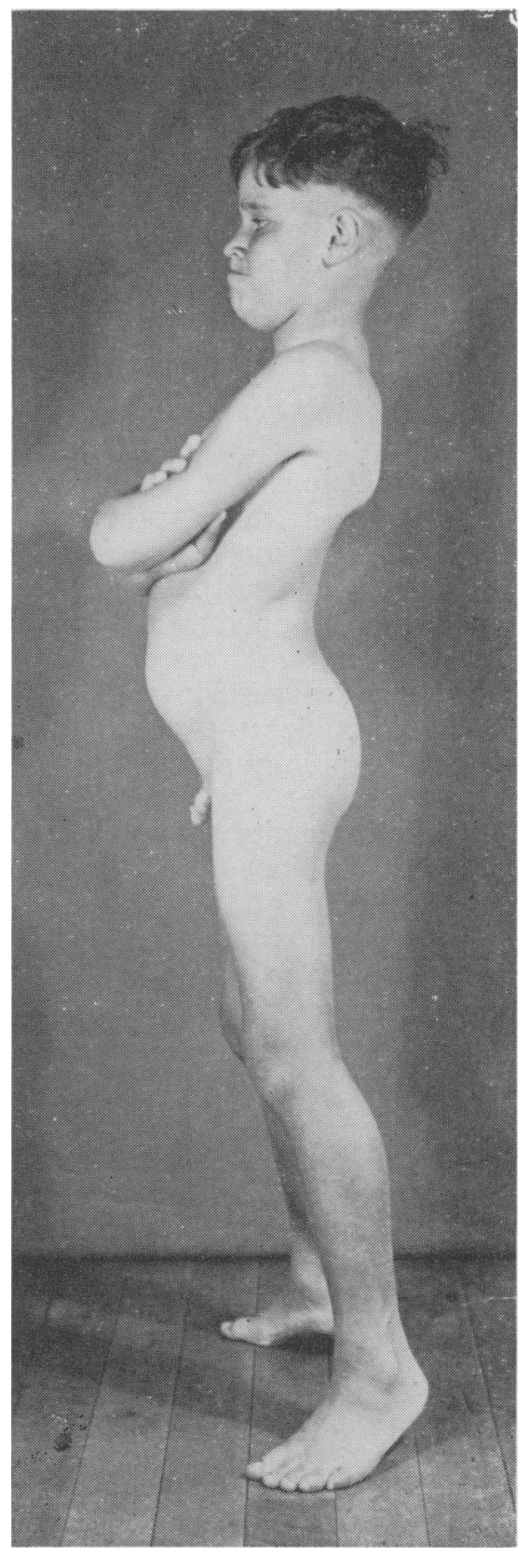

FIG 1.-Duchenne dystrophy. Note lumbar lordosifo and tendency to walk on toes.

1. Distal myopathy.

2. Ocular myopathy.

3. Congenital myopathy.

\section{The Myotonic Syndromes}

These are usually classified with the muscular dystrophies because they are genetically deter- -0 mined and the primary disease is in the muscle $\frac{\vec{D}}{0}$ Three forms are recognised:- 


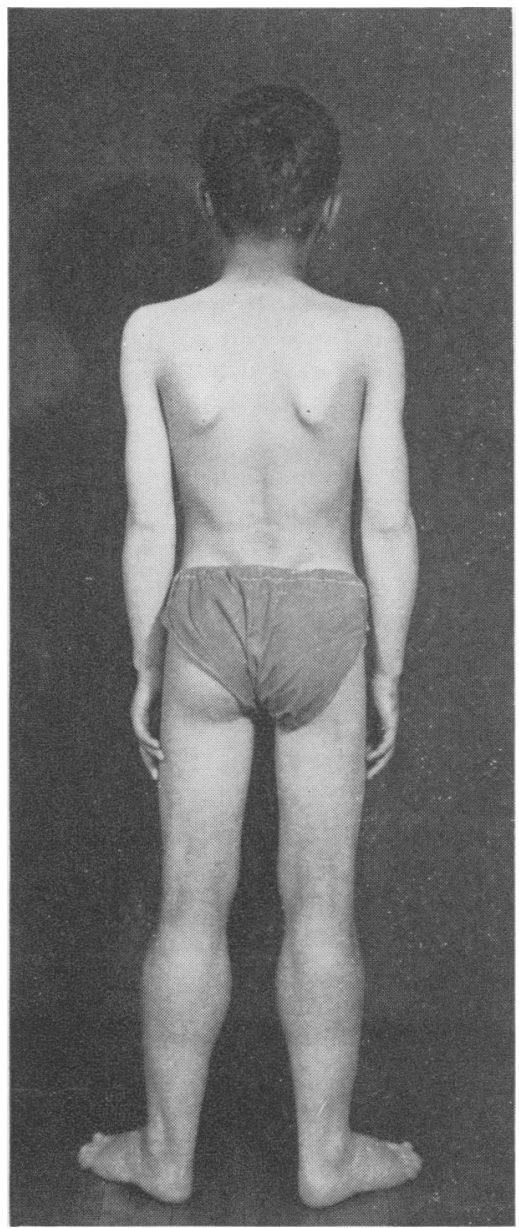

Fig. 2.-Duchenne dystrophy. Prominence of calves.

1. Myotonia congenita.

2. Dystrophia myotonica.

3. Paramyotonia congenita.

\section{CLINICAL ASPECTS}

\section{Duchenne Type}

Because of the sex-linked inheritance, the classical Duchenne type of muscular dystrophy characteristically affects boys. Female cases may be due to associated Turner's syndrome (Walton, 1955; Ferrier, Bamatter and Klein, 1965) or an autosomal recessive inheritance (Dubowitz 1960).

\section{Early features}

Symptoms are usually noted within the first three years of life. The commonest presenting symptoms are abnormality of gait and a tendency to fall.

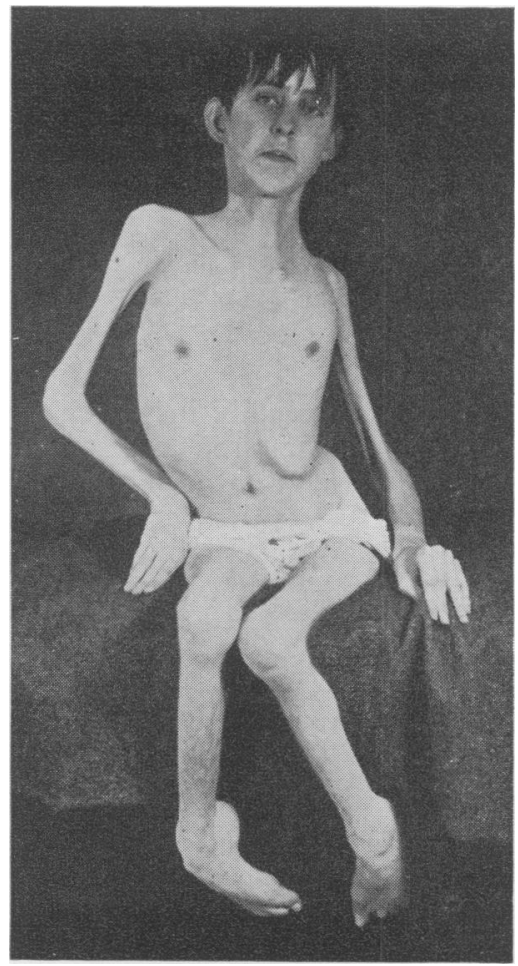

FIG. 3.-Advanced Duchenne dystrophy. Generalised wasting, scoliosis, equinovarus deformity of feet.

The gait is characteristically waddling and the child walks on a wide base with an associated lumbar lordosis, and may from an early stage tend to walk on his toes. (Fig. 1.)

These children fall frequently and the parents often comment on the fact that they fall quite suddenly, as if their feet were simply swept out under them. Initially they can get up again quite readily, after falling, but this becomes progressively more difficult and eventually they "climb up themselves" in a characteristic manner.

They have difficulty in climbing steps, and even the ascent of the kerb or a bus may require considerable effort. I have known a child to walk fairly steadily but to go spontaneously onto all fours when mounting the pavement.

They are never able to run normally. Any effort at running accentuates the abnormal gait and increases the tendency to fall.

Cramps in the calves and tightening of the calves "into a ball" are frequently noted in these children.

Prominence of the calf muscles is a common feature in the early stages. (Fig. 2). Other 
muscles such as the deltoids, brachioradialis, quadriceps, serratus anterior and sometimes the musculature generally may also show prominence. The tongue is also frequently enlarged.

Not all children show pseudohypertrophy. Some may show excessive atrophy from the early stages. In the later stages all become atrophic. (Fig. 3).

\section{Clinical Course}

The weakness gradually increases, but there may be periods of apparent arrest of progression for 6 to 12 months or longer. At other times there may be sudden rapid deterioration. The ability to walk is usually lost by the age of 12 years. Ambulation may be lost prematurely as a result of immobilisation even for short periods, following an illness, a fracture or an orthopædic procedure. In a study of 65 cases (Dubowitz, 1963a), 13 lost the ability to walk as a direct result of immobilisation. It is thus imperative for these children not to be confined to bed for minor illnesses or to be immobilized in plaster for minor fractures. Where immobilisation is unavoidable, intensive physiotherapy is essential.

Proximal muscles are always affected before the distal ones, and the lower limbs more severely than the upper. The trunk muscles are also affected. In time, the arms also become weak, initially the shoulder muscles and later those of the upper arm, forearm and hands. The child may retain the use of his hands, with elbows resting on a table, till late in the disease. Once they lose the ability to walk, the calves may lose their 'pseudohypertrophy' and become more atrophic.

The facial muscles are not affected till the very late stages, and then only slightly. Swallowing and sphincter control are usually normal. Histological changes, however, are present at autopsy in the facial and the external ocular muscles, and in the striated muscle of the pharynx and œsophagus. Cardiac muscle is also affected.

The reflexes show an unusual pattern of involvement (Dubowitz, 1964a). The upper arm reflexes are lost early, long before there is any striking weakness. The knee jerks are also absent early on, but the ankle joints are retained until late in the disease, and may even be abnormally brisk. I have seen unsustained ankle clonus in a number of instances. The plantar response is flexor.

These children usually die in their late teens. The most common cause of death is pueumonia and the associated involvement of the intercostal muscles and the diaphragm make even $a_{3}$ minor bronchitis a source of danger to thes child. Some children die acutely, in a mannerc similar to myocardial infarction. Cardiac involvement is well recognised in musculare dystrophy (Ross, 1883; Manning and Cropp? 1958). In the 65 cases I studied, over $90 \%$ had gross electrocardiographic abnormality while at autopsy three out of five cases showed $\mathbb{R}$ large macroscopic areas of fibrosis and all fives extensive histological changes (Dubowitz, 1963a).

Deformities. As long as the child is ambulant $\vec{\omega}$ he does not develop any fixed deformities. The lordosis with walking disappears on sittingo Some children tend to walk on their toes, even before there is any shortening of the tendo- $\rightarrow$ Achilles. I have recently given reasonsi for believing that all deformities in muscularo dystrophy are secondary to a constant posture and not primarily the result of muscle imbalance or asymmetrical muscle weakness (Dubowitz, 1964b). For this reasonI think that many of the deformities may be
potentially preventable.

Once the child loses the ability to wakke and is confined to a wheelchair he rapiefys develops flexion contractures of the elbows hips and knees, and if the feet hang uni supported, he will also develop severe equinovarus deformity. (Fig. 3). Scoliosis developsi as a result of the child leaning to one or othero side in his wheelchair, and it becomes pro- gressively worse and fixed. Moderate contracs tures of the knee, hip and elbow flexors are no disadvantage since the child can sit in his chair and sleep comfortably on his side. But the scoliosis can cause severe discomfort and also reduce the respiratory function.

Intellectual Impairment. A proportion of children with muscular dystrophy showi associated intellectual impairment. There has long been controversy as to whether this iso significant or not, and whether it is secondary to the physical disability. Walton and Nattrasso (1954) and Morrow and Cohen (1954) found no signficant intellectual impairment in theiro cases, while Allen and Rodgin (1960) and Worden and Vignos (1962) found a lowering in the I.Q. I have recently had the opportunityo of doing a prospective study of 3 early cases of muscular dystrophy and found evidence of intellectual impairment before the onset of severe physical handicap (Dubowitz, 1965). In two instances, a younger sibling without mus-0 cular dystrophy subsequently overtook the older艮 
brother in intellectual capacity. It is hard to explain why some children with Duchenne muscular dystrophy have an I.Q. of 50, while others with similar muscle disability are of grammar school standard. There may either be an associated sex-linked genetic mechanism causing intellectual impairment in some cases, or some metabolite of the degenerating muscle may in some instances affect the nervous system in the early phases. In neurogenic muscular atrophies of comparable severity there is no associated intellectual impairment (Dubowitz, 1964c).

Skeletal changes. Severe osteoporosis is common (Walton and Warrick, 1954) and fractures commonly follow minor trauma. They heal readily, however, without extensive or prolonged immobilisation. The bone changes are probably the result of the disease and absence of normal muscle stress on the bone, rather than an independent bone dystrophy. Similar changes and associated fractures are seen in neurogenic atrophies in childhood (Dubowitz, 1964c).

\section{Early Diagnosis}

Serum Enzymes. A number of serum enzymes are markedly elevated in muscular dystrophy. This is not peculiar to the muscular dystrophies, but also occurs in acquired primary myopathies such as polymyositis. It thus reflects a leakage of enzyme from the damaged muscle, rather than a primary enzyme block.

By and large the more acute and the more severe the myopathy the higher the enzyme levels. The highest levels are thus found in the early stages of the Duchenne-type dystrophies and they gradually approach normal levels in the terminal atrophic phases. These enzymes are thus valuable diagnostic tools. The most sensitive one is creatine phosphokinase (Ebashi, Toyokura, Momoi and Sugita, 1959; Dreyfus, Schapira and Demos, 1960). This enzyme has a normal upper level of 3.5 units, while in an early case of Duchenne dystrophy, figures of several hundred units are common and I have had one result of 1,200 units in an 18-month-old child. The enzyme level may be raised soon after birth even before clinical weakness is apparent. A normal level in infancy excludes the diagnosis. Other enzymes of practical use are the aldolase and the transaminases (Schapira, Dreyfus and Schapira, 1953; Pearson, 1957; Thomson, Leyburn and Walton, 1960). These parallel the creatine phosphokinase, but are not as markedly elevated.
Muscle biopsy. Characteristic pathological changes will confirm the diagnosis in a suspected case. Even in preclinical cases, extensive pathological changes are already present (Pearson, 1962), so that the disease undoubtedly starts in foetal life.

The electromyogram shows a characteristic pattern in myopathies, and is a useful diagnostic aid (Richardson, 1964).

\section{Detection of Carriers}

An abnormally high level of creatine phosphokinase (usually between 5 and 20 units) occurs in about $70 \%$ of known carriers (Schapira, Dreyfus, Schapira and Démos, 1960; Aebi, Richterich, Colombo and Rossi, 1962; Hughes 1962, 1963; Pearce, Pennington and Walton, 1964). While a high level of creatine kinase in a female sibling means she is a definite carrier, a normal level unfortunately still carries a $30 \%$ risk of a carrier state. Perhaps with further refinement of biochemical methods more accurate detection of carriers may be possible.

Histological abnormalities in the muscle of carriers have recently been recorded by Dubowitz (1963, b, c), Emery (1963, 1965), Pearson, Fowler and Wright (1963), and Walton (1964b). Abnormalities in the electromyogram were noted by Barwick (1963) and Van der Bosch (1963). These two additional investigations may be a useful ancillary aid in the diagnosis of possible carriers, particularly if the creatine phosphokinase level is normal.

\section{Genetic Counselling}

In a known female carrier there is a $50 \%$ risk of male children being affected, and a $50 \%$ chance of a female child being a carrier. It is thus of paramount importance to detect carriers as accurately as possible and to advise them of the risks.

\section{Differential Diagnosis}

Duchenne type muscular dystrophy may be closely mimicked by some forms of infantile spinal muscular atrophy (Dubowitz, 1964c) and by polymyositis (Walton and Adams, 1958).

In neurogenic atrophies, distinction is usually easy on the basis of normal or near normal serum enzyme levels and typical features on histology and electromyography. Polymyositis may give a high enzyme level in the blood and diagnosis often has to rest on variations in the clinical pattern and course, on the muscle histology, and on possible electromyographic differences. 


\section{Treatment}

Active physiotherapy with a full range of passive movements of all joints may prevent contractures or slow their progression. This can be done by the parents at home. Particular attention should be paid to the ankles in the ambulant child.

At the stage while the child is still able to stand, but can only barely walk, the fitting of light-weight calipers, together with intensive physiotherapy may prolong ambulation for several years (Vignos and Archibald, 1960; Spencer and Vignos, 1962).

Adequate bracing of the spine is essential as soon as the child loses the ability to walk, in order to prevent scoliosis. Attention should also be paid to the posture, and passive movements of limb joints to prevent severe contractures and deformities (Dubowitz, 1964b).

Respiratory infections require intensive therapy with antibiotics and physiotherapy. No drug therapy has yet been of proven value in influencing the progression of muscular dystrophy.

\section{Limb Girdle Type}

This form affects males and females. Symptoms usually start in adolescence or early adult life, but the onset may date to early childhood or occur as late as the 5th or 6th decade. In Walton's classification both the shoulder girdle and the pelvic girdle varieties fall in this group.

In the scapulo-humeral variety the initial disability may be slight, and restricted to movements such as abduction of the shoulders. It may slowly spread to more distal arm muscles, and later to the legs. Ambulation may not be lost at all or may occur very late in the disease.

Marked atrophy of the shoulder girdle muscles may occur and the weakness may be asymmetrical. The neck and trunk muscles may also be affected, but the face is spared.

The pelvic girdle form has a similar distribution to the Duchenne type and may also present with a waddling gait and lumbar lordosis (Fig. 4). Prominence of the calf muscles or other muscles, such as the quadriceps, may occur (Fig. 5), while other muscles may be atrophic. Weakness may be asymmetrical and one sometimes observes atrophy in only part of a muscle, e.g., the hamstrings, giving an appearance as if scalloped out.

The course of the disease is much slower than the Duchenne type, but there is often quite considerable disability after a number of years. Loss of ambulation may occur 15 or

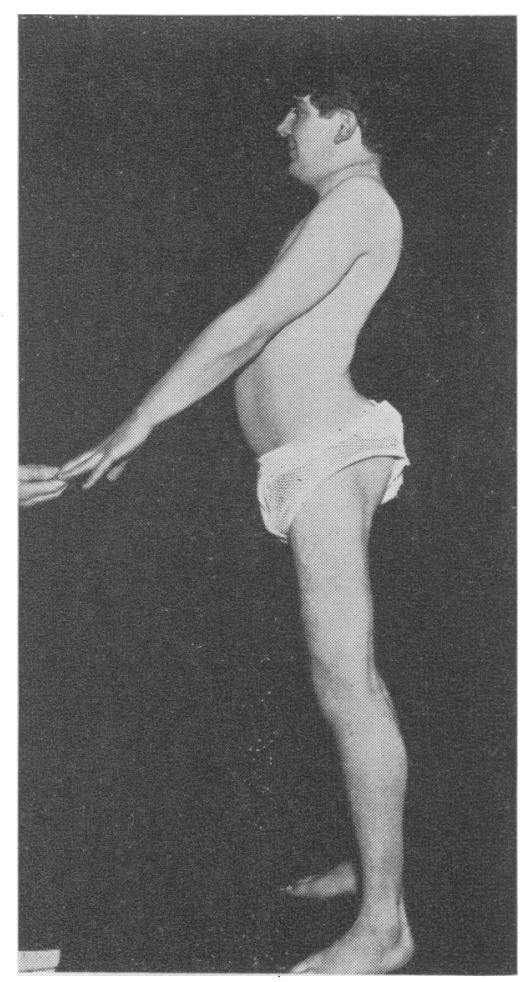

FIG. 4.-Limb-girdle dystrophy. Lumbar lordosis

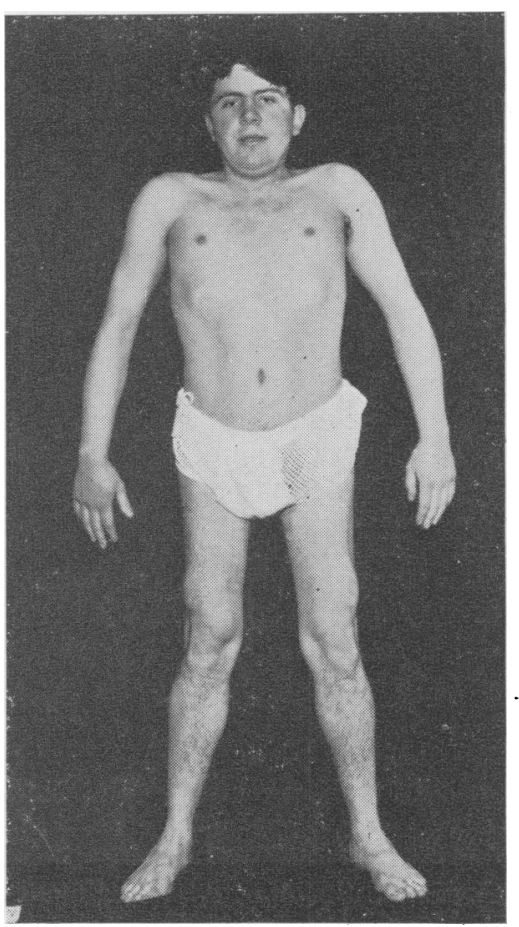

Fig. 5.-Limb-girdle dystrophy. Prominence of vastus lateralis and calves. 
20 years or more after the onset. There is no clearcut dividing line between the milder extreme of the Duchenne type and the severe end of the spectrum of limb girdle type. The tendon reflexes are retained longer than in the Duchenne type, but may eventually become depressed or absent.

Deformities are late and, as in the Duchenne type, tend to occur after loss of ambulation. Osteoporosis may also occur but is less severe than in the Duchenne type and fractures are uncommon.

Cardiac involvement is also uncommon and intelligence is not impaired.

\section{Diagnosis}

The serum enzyme levels may be moderately elevated but some cases have normal levels (Thomson, Leyburn and Walton, 1960; Dreyfus and Schapira, 1962).

Muscle biopsy shows the characteristic features of a myopathy but the changes are not as striking as in the Duchenne type. In some cases with clinical 'pseudohypertrophy' I have observed no proliferation of fat or connective tissue as in the Duchenne type, but a true hypertrophy of most of the muscle fibres.

\section{Differential diagnosis}

Proximal neurogenic atrophy of the type described by Wohlfart, Fex and Eliasson (1955), and by Kugelberg and Welander (1956), may give an identical clinical picture to limb girdle dystrophy. Inheritance is also by an autosomal recessive gene. It may be distinguished by serum enzyme levels, muscle biopsy and EMG findings. The subacute and chronic forms of polymyositis may also give a similar clinical picture. (Walton and Adams, 1958; Barwick and Walton, 1963). The following case histories illustrate some of the features of limb-girdle dystrophy:

A 17-year-old girl was referred for genetic counselling. She had been diagnosed as 'pseudohypertrophic muscular dystrophy'. She had a tendency to fall since the age of 5 and difficulty in climbing steps since about 11. Progression was very slight.

She walked with a slightly waddling gait and had minimal weakness of the pelvic girdle muscles. There was prominence of the calves and the vastus lateralis bilaterally. The serum enzymes were markedly elevated (SGOT 200 King units $/ \mathrm{ml}$. SGPT 70 units $/ \mathrm{ml}$., aldolase 112 units, creatine kinase 56 $\mu \mathrm{m} / \mathrm{ml}$. /hr.).

Her 20-year-old brother has a similar affliction (Figs. 4 \& 5). He was found to have a more marked weakness than his sister, and a more striking waddling gait, on a broad base with associated lordosis. He climbed up himself when getting up from the floor. His weakness was first noted after a fracture of the femur at 13. He was, however, not severely disabled and could drive a car. There was striking prominence of the vastus lateralis and calf muscles. Serum enzymes were grossly elevated (SGOT 280, SGPT 220 , aldolase 130 , creatine kinase 122 ).

Biopsy of the vastus lateralis in both these patients showed marked variation in fibre size with many abnormally large fibres $(60-120 \mu)$, many fibres with internal nuclei and occasional fibres undergoing degeneration and phagocytosis. There was no excess of adipose or connective tissue.

Both parents are normal. The inheritance is by an autosomal recessive mechanism and one could advise both patients that there was little risk of carrying the disease to a child.

\section{Facio-Scapulo-Humeral Type}

This is the most benign form of the common muscular dystrophies. It affects both sexes and as it is inherited as a dominant trait, multiple cases often occur in a family.

The facial muscles are often affected first in early infancy, and weakness of the shoulder girdle may even be delayed until adult life. There is considerable variation in severity, not only in different families, but also in individual members of the same family. Abortive cases are common and are readily missed unless all members of the family are carefully examined.

Progression may be so slow that the disease appears to be static. In many instances the life span may be normal. Other cases, however, may lose ambulation by adolescence due to pelvic girdle involvement.

The pattern of weakness in the limbs is similar to that of the other dystrophies, affecting proximal more than distal muscles. Thus the clinical features of the scapulo-humeral or pelvic girdle involvement may resemble the limb girdle dystrophies.

The facial weakness results in the characteristic myopathic facies, with absence of expression, pouting lips, and limitation of normal movement. In a mild case a useful diagnostic sign of minimal involvement is inability to shut the eyes tightly and to bury the eyelashes. In severe cases the weakness of the face may be gross.

\section{Diagnosis}

Serum enzymes may be normal or slightly elevated.

Muscle biopsy shows evidence of mild or moderate myopathic changes.

The following case histories are fairly representative: -

A 25-year-old twin brother and sister were referred because of their muscle disease. Weakness in the girl was first noted at the age of 9 when she began to fall and drag her right leg. This has gradually got worse, and she is now practically confined to a 


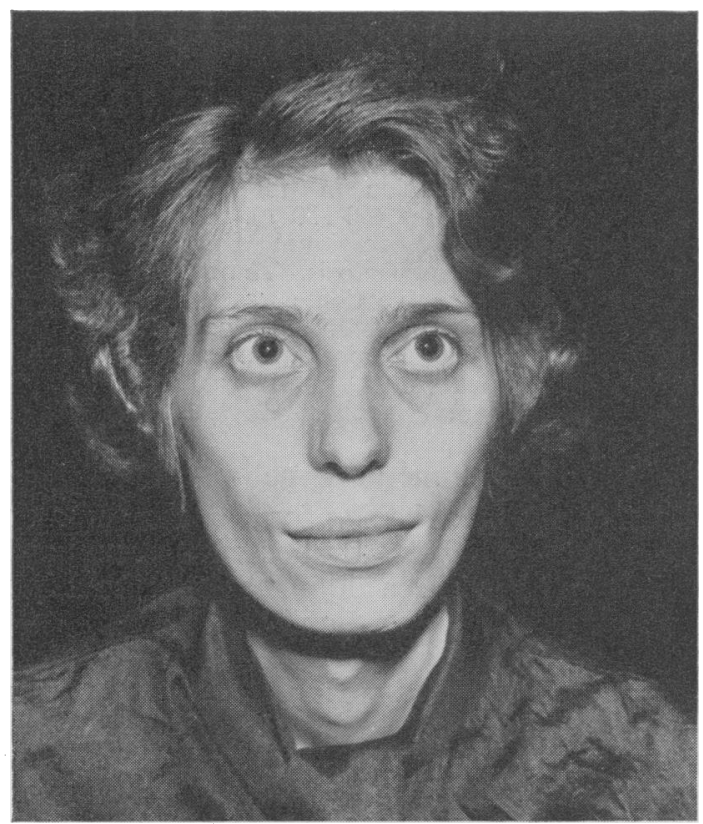

Fig. 6.-Facio-scapulo-humeral dystrophy. Myopathic facies.

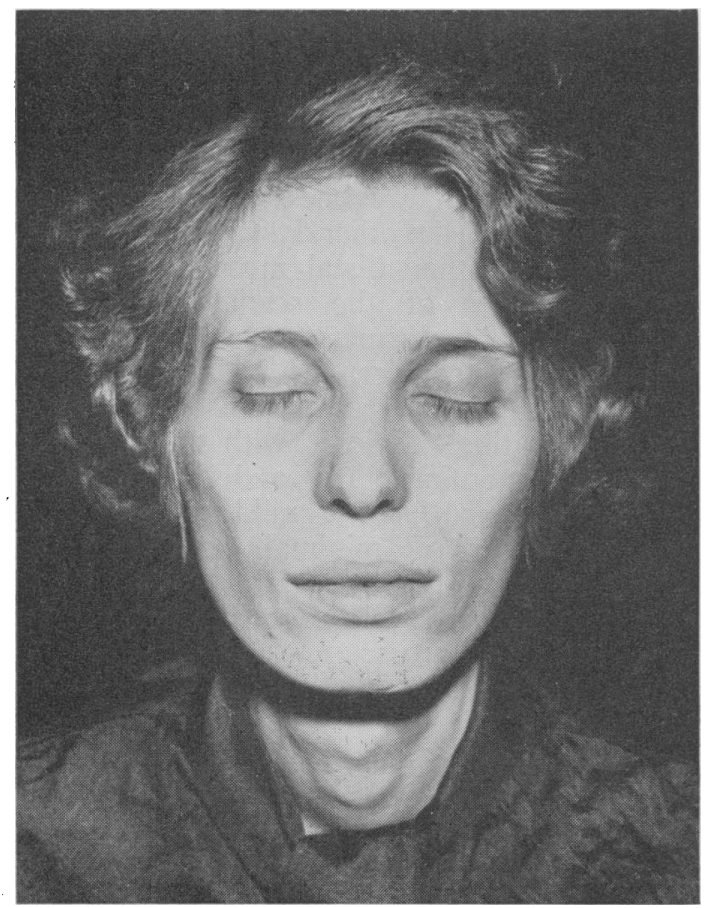

Fig. 7. - Same patient. Inability to bury eyelashes.

wheelchair. She has a myopathic face and extensive weakness and wasting of the shoulder and pelvic girdles (Figs. 6, 7, 8). Facial weakness probably preceded the girdle weakness. Her brother who is

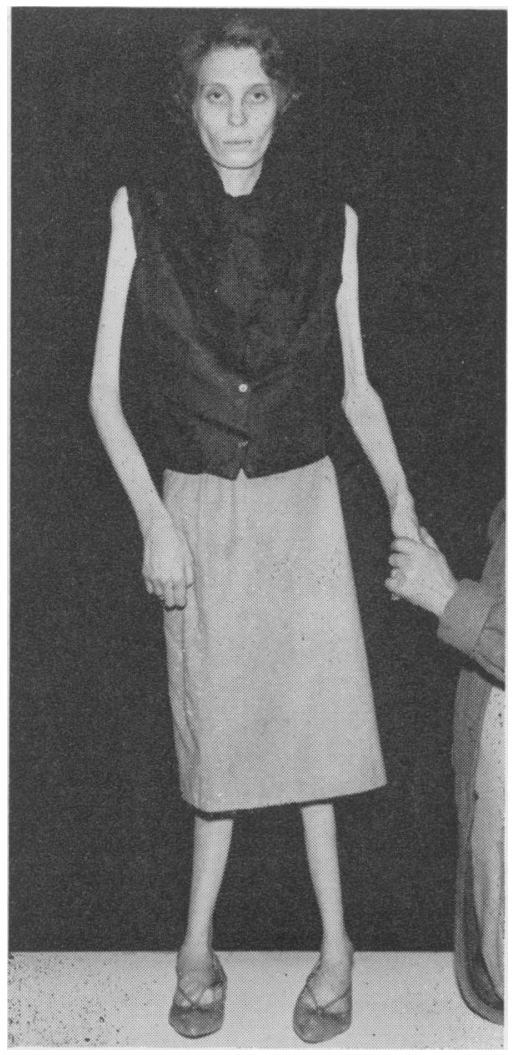

FIG. 8.-Same patient. Generalised wasting.

less severely affected, is still ambulant. He has a waddling gait and lumbar lordosis. He is unable to get up from the floor without support. He also has $\overline{0}$ a myopathic facies. His lower limb weakness also 3 started at about 9, but the progression was slower.

The mother has a slight waddle but only minimalo pelvic girdle and scapulo-humeral weakness. She has a myopathic facies and is unable to bury her eyelashes.

A female sibling, aged 10, thought by the mother 0 to be normal, has a myopathic facies and is unable 3 . to bury her eyelashes (Fig. 9). She also has minimal shoulder girdle weakness. Two other siblings are $\frac{3}{3}$ normal.

The serum enzyme levels are normal in the severely은 affected girl, and slightly elevated in the other $3_{D}$ affected patients.

\section{Rare Myopathies \\ Distal Myopathy}

This form was first described by Gowers $N$ (1902). It begins in the peripheral muscles of ${ }^{N}$ the limbs and very slowly spreads proximally. It is rare in this country, but fairly common inco Sweden, where it is inherited as an autosomal $\mathbb{\complement}$ dominant (Welander, 1951, 1957). It is impor-? tant to differentiate it from peroneal muscular 0 atrophy, an hereditary neuropathy, which is $\frac{\vec{\Phi}}{\mathbb{D}}$ more common. 


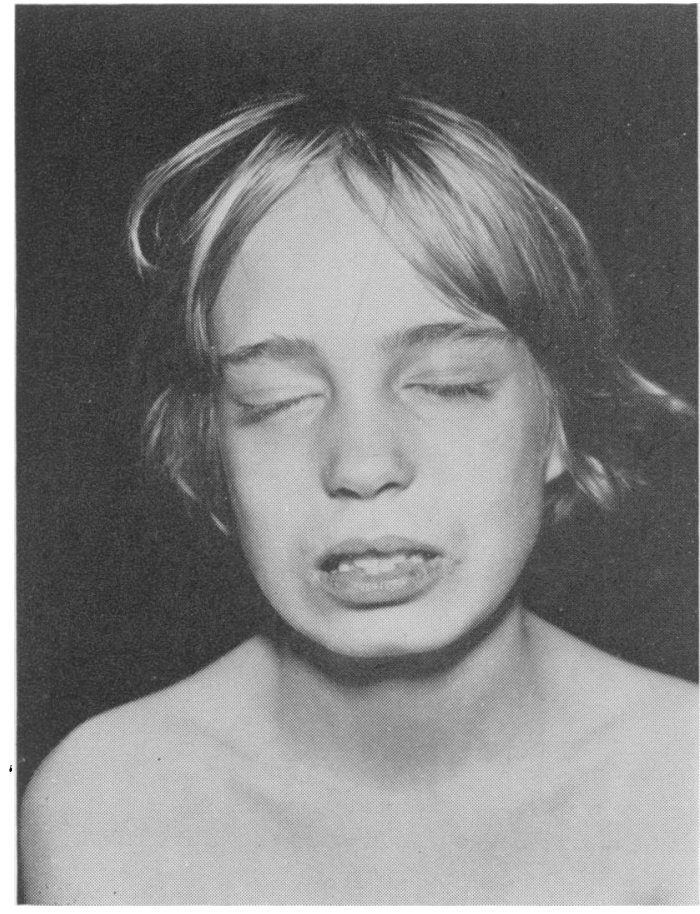

FIG. 9.-Facio-scapulo-humeral dystrophy. Sibling of patient in Fig. 8. Early facial involvement. Inability to bury eyelashes. No limb weakness.

\section{Ocular Myopathy}

This form has recently been reviewed by Kiloh and Nevin (1951). In addition to ptosis and external ophthalmoplegia, the facial muscles, and later the limb muscles, may also be affected. Inheritance is usually by an autosomal dominant mechanism. Clinical differentiation from myasthenia gravis is important and there may also be a superficial resemblance to the facio-scapulo-humeral type. Some cases of congenital ptosis probably also fall in this category.

\section{Congenital Myopathy}

Although a number of case reports have appeared from time to time of a congenital myopathy, the majority have not had sufficient support from unequivocal histological changes, absence of degeneration of the anterior horn cells of the cord, and the presence of raised serum enzymes. Many are probably examples of neurogenic atrophies or congenital hypotonia. Some cases of arthrogryposis may be due to a congenital myopathy (Banker, Victor and Adams, 1957).

\section{Central Core Disease}

This non-progressive myopathy was first

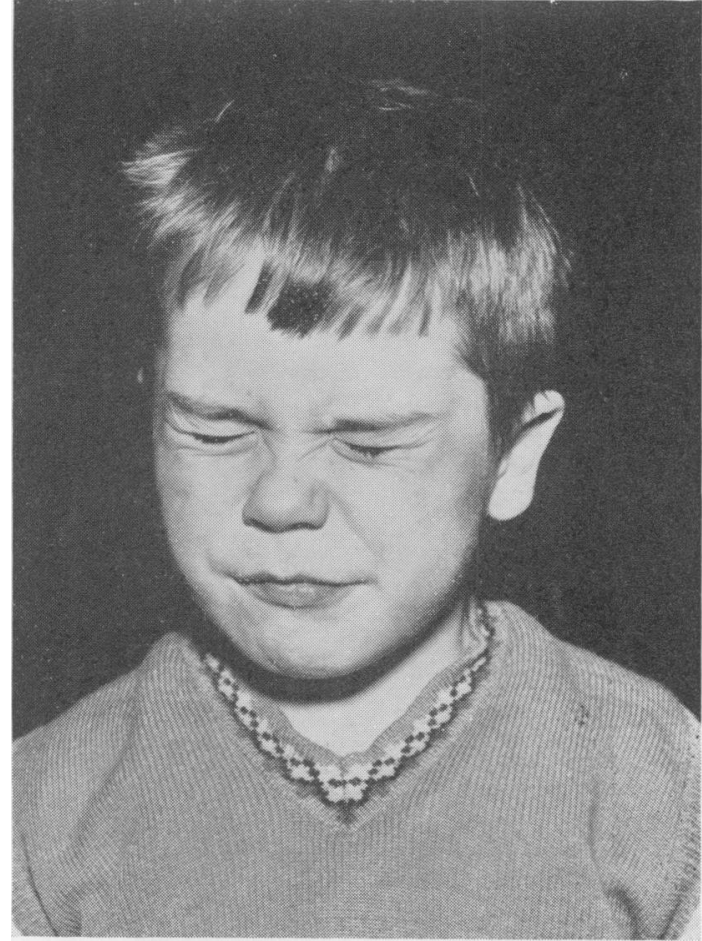

FIG. 10.-Normal child for comparison.

described in 5 members of a family by Shy and Magee (1956). In this family it was inherited as a dominant character, presented as hypotonia in infancy, and was characterised by central cores in the muscle fibre which stained differently from the rest of the fibre with trichromes stains. Another example was diagnosed in England (Engel, Foster, Hughes, Huxley, Mahler, 1961) but no other members of the family were affected. Histochemical studies showed the cores to be devoid of any enzyme activity, and presumably non-functioning (Dubowitz and Pearse, 1960).

\section{Myotonic Syndromes}

a) Myotonia congenita.

b) Dystrophia myotonica.

c) Paramyotonia congenita.

These conditions are usually classified with the muscular dystrophies because they are genetically determined and the primary abnormality is within the muscle itself. However, in myotonia congenita there may be no weakness or wasting and no progression.

Although there may be some overlap between myotonia congenita and dystrophia myotonica 

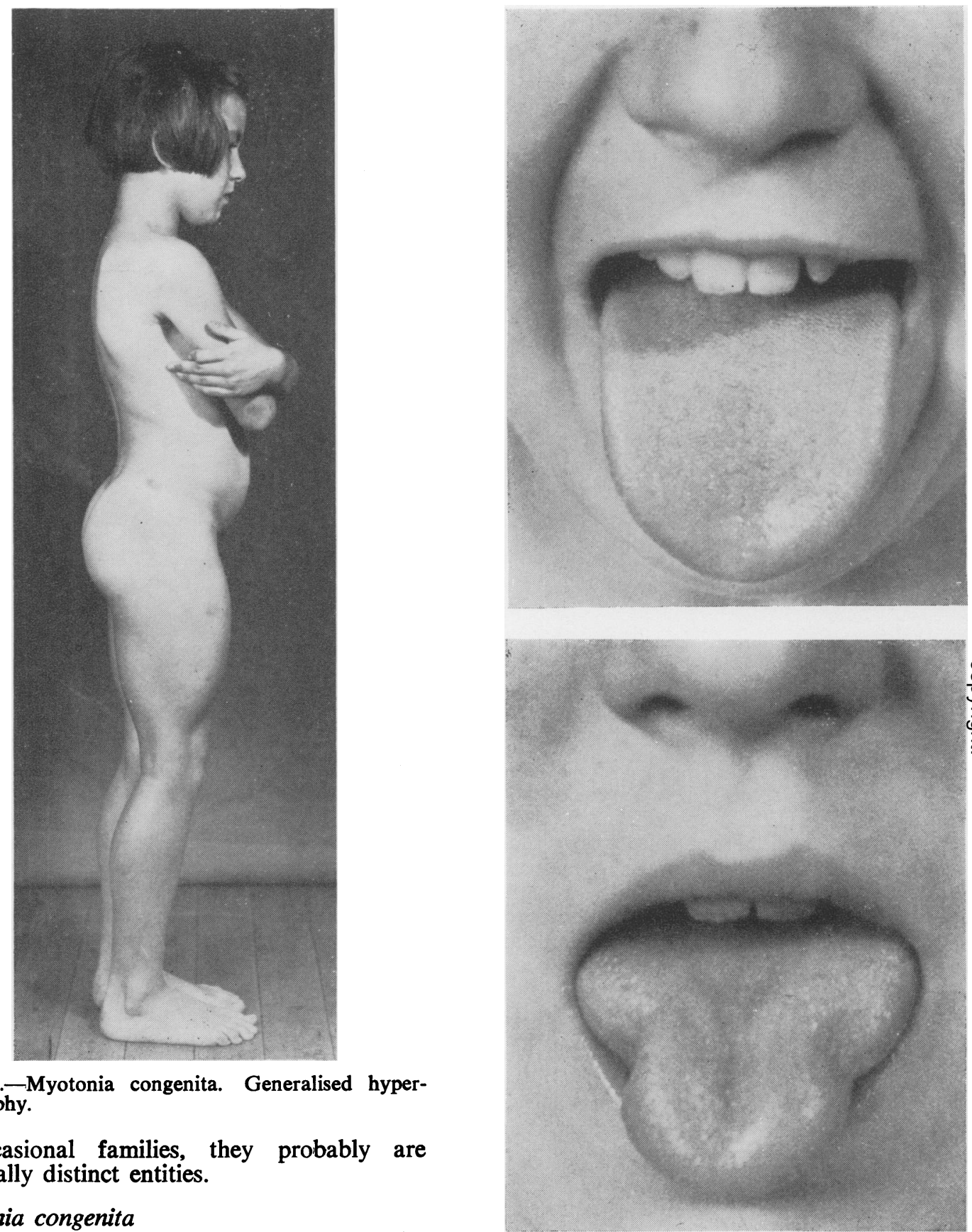

FIG. 11.-Myotonia congenita. Generalised hypertrophy.

in occasional families, they probably are genetically distinct entities.

\section{Myotonia congenita}

This disease was first described in 1876 by a Danish physician Thomsen, himself a sufferer from the disease, in order to save his affected son from being conscripted into the Prussian Army.

The condition is characterised by the inability of muscle to relax after prolonged voluntary contraction. It tends to diminish and sub-

FIG. 12.-(a, b) Myotonia congenita. Percussion myotonia of tongue.

sequently disappear after repetitive voluntary movements. The condition may be recognised in infancy by a delay in opening the eyes after ${ }^{\circ}$ crying. In older persons inability to relax the $\stackrel{\vec{D}}{\stackrel{\circ}{*}}$ grip is a common sign. 


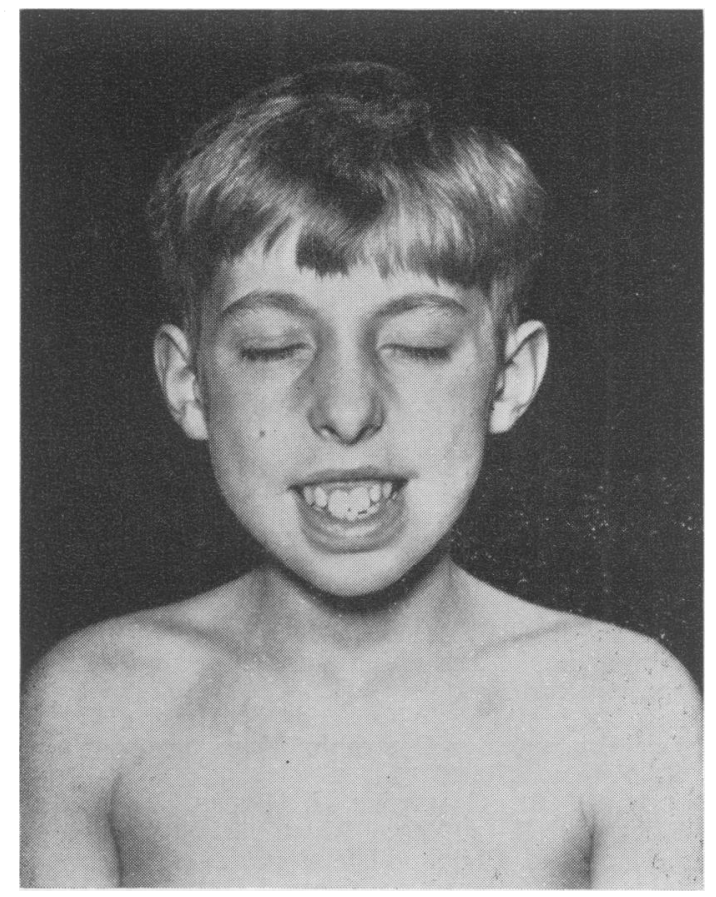

Fig. 13.-Dystrophia myotonica. Early facial involvement.

However, the myotonia may be so slight that it is difficult to demonstrate and the initial diagnosis is often made mainly on the basis of a careful history, as illustrated in the following patients: -

An 8-year-old girl had consulted many doctors since the age of two without a firm diagnosis being made. The most frequent diagnosis was neurosis or hysteria (mother or child).

She gave a classical history of myotonia congenita. When she woke up in the morning she was so stiff, she literally rolled out of bed. She could scarcely walk down the stairs, but once she got moving, she became quite normal. At school she was fond of competitive running but she was often left behind, glued to the starting post, but once she got going she often overtook her competitors. When watching television she was usually unable to get up again because of stiffness.

On examination there was generalised hypertrophy of muscle (Fig. 11) but no weakness. After repeated attempts, percussion myotonia of the tongue was elicited (Fig. 12) and subsequently also of the thenar muscles.

Another girl seen recently, gave a very similar history to the above. Her father had been treated for Perthes' disease for the past 20 years. He gave a classical symptom of myotonia. When going to the cinema he always sat on the aisle so that he could keep his legs moving, or else he became so stiff that he could not get up after the show. His mother had similar symptoms.

While this condition may be so mild as to cause very little disability, there are certain occupational hazards-throwing a handgi enade, for example.

\section{Diagnosis}

Electromyography is useful in confirming diagnosis and gives a characteristic afterdischarge after voluntary contraction, with a 'dive bomber' sound when amplified.

Serum enzymes are usually normal. Muscle biopsy shows hypertrophied fibres with internal nuclei.

\section{Dystrophia Myotonica}

This condition, first described by Steinert (1909) and Batten and Gibb (1909), has recently been extensively reviewed by Thomasen (1948), and de Jong (1955).

In addition to myotonia there is wasting and weakness of the facial, sternomastoid and limb muscles. Distal muscles may be affected more than the proximal and the weakness may be asymmetrical.

Additional features of the syndrome include cataracts, frontal baldness and testicular or ovarian atrophy. Cardiac abnormalities, particularly conduction defects, are common.

While many cases only start in adolescence or adult life, it may begin in infancy (Dodge, Gamstorp, Byers, Russell, 1965) and early signs of facial weakness or myotonia should be looked for in affected families. There may be associated intellectual impairment.

Inheritance is by an autosomal dominant. Diagnosis may be difficult in the early stages. Recently a 10-year-old boy, whose 36-year-old mother has dystrophia myotonica with associated cataracts, was assessed. He has no physical disability. He was found to have a myopathic facies with an ability to bury the eyelashes (Fig. 13). Myotonia could not be elicited.

\section{Paramyotonia Congenita}

First described by Eulenberg (1886), this is probably a variant of myotonia congenita, in which myotonia is precipitated by cold. It may be associated with attacks of muscle weakness resembling periodic paralysis and there may also be some resemblance to adynamia episodica hereditaria (Gamstorp, 1956), which is also transmitted through an autosomal dominant gene.

Treatment. While there is no effective drug therapy for the weakness or wasting of dystrophia myotonica, the myotonia in this condition as well as in myotonia congenita can be improved with quinine (Wolf, 1936; Kolb, Harvey and Whitehill, 1938; Waring, Ravin and Walker, 1940), procaine amide (Geschwind 
and Simpson, 1955) and cortisone (Shy and McEachern, 1951; Liversedge and Newman, 1956). Leyburn and Walton (1959), have compared the different forms of therapy in a controlled trial.

In the majority of cases of myotonia congenita, particularly in childhood, the disability may be so slight that prolonged drug therapy is unnecessary. In many cases of dystrophia myotonica, the myotonia may be much less important a symptom than the severe wasting and weakness.

\section{General Conclusions}

In writing a review on muscular dystrophy and related disorders, it is difficult to know exactly where to draw the boundary. Today it is still customary to draw a clear-cut distinction between the hereditary muscular dystrophies on the one hand and metabolic and acquired myopathies on the other. I think this distinction is probably artificial. Some metabolic myopathies e.g. McArdle's disease, due to a single enzyme defect, are genetically determined. As our knowledge expands some of the hereditary muscular dystrophies will undoubtedly also join the group of inborn errors of metabolism.

I wish to thank Mr. A. T. Tunstill and Miss Mary Pugh for the illustrations.

\section{REFERENCES}

Aebi, U., Richterich, R., and Colombo, J. P. (1962): Progressive Muscular Dystrophy. II. Biochemical Identification of the Carrier State in the Recessive Sex-linked Juvenile (Duchenne) Type by Serum Creatine-phosphokinase Determinations, Enzymol biol. Clin., 1, 61.

Allen, J. E., Rodgin, D. W. (1960): Mental Retardation in Association with Progressive Muscular Dystrophy, Amer. J. dis. Child., 100, 208.

ARAN, F. A. (1850): Réchèrches sur une Maladie non Encore Décrite du Système Musculaire (Atrophie Musculaire Progressive), Arch. gén. Méd., 24, 5.

BANKer, B. Q., Victor, M., and AdAMS, R. D. (1957): Arthrogryposis Multiplex due to Congenital Muscular Dystrophy, Brain, 80, 319.

BARWICK, D. D. (1963): Investigations of the Carrier State in Duchenne Type Dystrophy. In "Research in Muscular Dystrophy", p. 10, London: Pitman.

BARWICK, D. D., and WALton, J. N. (1963): Polymyositis, Amer. J. Med., 35, 646.

BATTEN, F. E., and GIBB, H. P. (1909): Myotonia Atrophica, Brain, 32, 187.

BECKER, P. E. (1953): Dystrophia Musculorum Progressiva. Ein Genetische und Klinische Untersuohing der Muskeldytrophien. Stuttgart: Georg Thieme.

BECKER, P. E. (1957): Neue Ergebnisse der Genetik der Muskeldystrophien, Acta Genet. med. (Roma), 7, 303.

BeCKer, P. E. (1962): Two New Families of Benign Sex-linked Recessive Muscular Dystrophy. Rev. canad. Biol., 21, 551.
Becker, P. E., and Kiener, F. (1955): Eine Neue X-chromasalmale Muskeldystrophie, Z. neurol., 193, 凤 427.

BELL, C. (1830): The Nervous System of the Human Body, p. 161. London: Longmans.

Bell, J. (1943): On Pseudohypertrophic and Allied Types of Progressive Muscular Dystrophy. The $\overline{\bar{N}}$ Treasury of Human Inheritance. IV. London: Cambr. Univ. Press.

BLYTH, H., and PUGH, R. J. (1959): Muscular음 Dystrophy in Childhood. The Genetic Aspect, $\frac{\bar{\omega}}{\bar{\Phi}}$
Ann. hum. Genet. Lond., 23, 127.

Chung, C. S., and MorTon, N. E. (1959): Discrimination of Genetic Entities in Muscular कै

Dystrophy, Amer. J. hum. Genet, 11, 339.
Coste, and GiOJA (1838): Ann. clin. osp. inc. Nap. $\vec{\circ}$ (quoted by Schmidt 1839).

DARWELl, J. (1830): Cases of a Peculiar Species of $\vec{\omega}$ Paralysis, Lond. med. Gaz., 7, 201.

DAVIDENKOW, S. (1930): Ueber die Vererbung der윽 Dystroph. Musc. Progr. und ihrer Unterformen, $\underline{3}$ Arch. Rass. Gesellsch. biol., 22, 169.

DE JoNG, J. G. Y. (1955): Dystrophia Myotonica, Paramyotonia and Myotonia Congenita. Assen: van Gorcum.

DIEHL, F., HANSEN, K., and v. UBISCH (1927): w Der Erbgang der Dystroph. Musc. Progr., Dtsch. N Z. Nervenheilk, 99, 54.

DODGE, P. R., GAMSTORP, I., BYERS, R. K., and Russell, P. (1965): Myotonic Dystrophy in Infancy and Childhood, Pediatrics, 35, 3.

DREYFus, J. C., SCHAPIRA, G., and Demos, J. (1960): Ф Etude de la Créatine-kinase Sérique chez les $\vec{c}$ Myopathes et leur Familles, Rev. franc. Etud. clif biol, 5, 384.

DREYFUS, J. C., and SchapIRA, G. (1962): Big̀: chemistry of Hereditary Myopathies. Springfiel Illinois: Charles C. Thomas.

Dubowitz, V. (1960): Progressive Muscular Dys- $\overline{0}$ trophy of the Duchenne type in Females and its Mode of Inheritance, Brain, 83, 432.

Dubowitz, V. (1963a): Some Clinical Observations $\stackrel{\varrho}{\vec{t}}$ on Childhood Muscular Dystrophy, J. clin. Pract., 음 17, 283.

DuBowITZ, V. (1963b): Myopathic changes in a Muscular Dystrophy Carrier, J. Neurol. Neurosurg. Psychiat., 26, 322.

Dubowitz, V. (1963c): Myopathic Changes in Muscular Dystrophy Carriers, Proc. roy. Soc. Med., 56, 810.

Dubowitz, V. (1964a): The Reflexes in Progressive Muscular Dystrophy, Rev. Med. Child. Neurol., 6,, 621.

Dubowitz, V. (1964b): Progressive Muscular Dystrophy: Prevention of Deformities, Clin. 을 Pediat., 3, 323.

DuBOwITZ, V. (1964c): Infantile Muscular Atrophy. A Prospective Study with Particular Reference to a Slowly Progressive Variety, Brain, 87, 707. O

DuBowITZ, V. (1965): Intellectual Impairment in Muscular Dystrophy, Arch. Dis. Child. in press. O

Dubowitz, V., and Pearse, A. G. E. (1960): Oxida- $N$ tive Enzymes and Phosphorylase in Central-core $\sigma$ Disease of Muscle, Lancet, ii, 23.

DuCHENNE, G. B. (1861): De l'Electrisation localisée et son Application à la Pathologie et à la Thérapeutique. 2nd Edit. Paris: Bailliere.

DUCHENNE, G. B. (1868): Recherches sur la Paralysie $\square$ Musculaire Pseudohypertrophique ou Paralysie $\bar{D}$ Myosclerosique, Arch. gén. Méd., 11, 5, 179, 305, 421, 552. 
DuchenNe, G. B. (1872): De l'Electrisation Localisee et son Application à la Pathologie et a la Thérapeutique. 3rd Edit. Paris: Bailliere.

Ebashi, S., Toyokura, Y., Momoi, H., and Sugita, H. (1959): High Creatine Phosphokinase Activity of Sera of Progressive Muscular Dystrophy Patients, J. Biochem. (Tokyo), 46, 103.

EMERY, A. E. H. (1963): Clinical Manifestations in Two Carriers of Duchenne Muscular Dystrophy, Lancet, i, 1126.

EMERY, A. E. H. (1965): Muscle Histology in Carriers of Duchenne Muscular Dystrophy, J. med. Genet., 2, 1.

Engel, W. K., Foster, J. B., Hughes, B. P., Huxley, H. E., and MaHLeR, R. (1961): Central Core Disease. An Investigation of a Rare Muscle Cell Abnormality, Brain, 84, 167.

ERB, W. (1884): Ueber die "Juvenile Form" der Progressive Muskelatrophie; ihre Beziechungen zur Sogenannten Pseudohypertrophie der Muskeln, Disch. Arch. klin. Med., 34, 467.

ERB, W. (1891): Dystrophie Muscularis Progressiva. Klinische und Pathologisch-anatomische Studien, Dtsch. Z. Nervenheilk, 13, 173.

EULENBERG, A. (1886): Ueber eine Familiare, durch 6 Generationen Vervolgbare Form Congenitaler Paramyotonie, Neurol. Zbl., 5, 265.

Ferrier, P., Bamatter, F., and Klein, D. (1965): Muscular Dystrophy (Duchenne) in a Girl with Turner's Syndrome, J. med. Genet., $2,38$.

GAMSTORP, I. (1956): Adynamia Episodica Hereditaria, Acta pediat. (Uppsala) Suppl., 108.

GeschwiNd, N. A., and SimPSON, J. A. (1955): Procaine Amide in the Treatment of Myotonia, Brain, 78, 81 .

Gowers, W. R. (1879): Clinical Lecture on Pseudohypertrophic Muscular Paralysis, Lancet, ii, 1, 37, $73,113$.

GOWERS, W. R. (1902): A Lecture on Myopathy and a Distal Form, Brit. med. J., ii, 89.

Hughes, B. P. (1962): Serum Enzyme in Carriers of Muscular Dystrophy, Brit. med. J., ii, 963.

Hughes, B. P. (1963): Serum Enzyme Studies with Special Reference to Duchenne Type Dystrophy. In "Research in Muscular Dystrophy", p. 167. London: Pitman.

KILOH, L. G., and Nevin, S. (1951): Progressive Dystrophy of External Ocular Muscles (Ocular Myopathy), Brain, 74, 115.

Kolb, L. C., Harvey, A. M., and Whitehill, M. R. (1938): A Clinical Study of Myotonic Dystrophy and Myotonia Congenita with Special Reference to the Therapeutic Effect of Quinine, Bull Johns. Hopk. Hosp., 62, 188.

Kugelberg, E., and Welander, L. (1956): Heredofamilial Juvenile Muscular Atrophy Simulating Muscular Dystrophy, Arch. Neurol., 75, 500.

LANDOUZY, L., and DEJERINE, J. (1884): De la Myopathie Atrophique Progressive (Myopathie Héreditaire), Debutant, dans l'Enfance, par la Face, sans Altération du Système Nerveux, C.R. Acad. Sci. (Paris), 98, 53.

Levison, H. (1951): Dystrophia Musculorum Progressiva; Clinical and Diagnostic Criteria; Inheritance, Copenhagen: Ejnar Munksgaard.

LeYburN, P., and WaltoN, J. N. (1959): The Treatment of Myotonia: a Controlled Trial, Brain, 82, 81.

LEYDEN, E. (1876): Klinik der RüchenmarksKrankheiten, Hirschwald., 2, 447.
Liversedge, L. A., and Newman, M. J. D. (1956): The Treatment of Myotonia, Brain, 79, 395.

Manning, G. W., and CROPP, G. J. (1958): The Electrocardiogram in Progressive Muscular Dystrophy, Brit. Heart J., 20, 416.

Meryon, E. (1852): On Granular and Fatty Degeneration of the Voluntary Muscles, Med. Chir. Trans., 17, 73.

Milhorat, A. T., and WolfF, H. G. (1943): Studies in Diseases of Muscle. Heredity of Progressive Muscular Dystrophy; Relationship between Age at Onset of Symptoms and Clinical Course, Arch. Neurol. Psychiat. (Chicago), 49, 641.

MinkowSKI, M., and SidLeR, A. (1928): Klinische und Genealogische Untersuchungen zur Kenntnis der Progr. Muskeldystrophie, Arch. Julius Klaus. Stift., 3, 239 .

Morton, N. E., Chung, C. S., and Peters, H. A. (1963): Genetics of Muscular Dystrophy. In "Muscular Dystrophy in Man and Animals", edit. G. H. Bourne and N. Golarz, p. 324. Basel and New York: Karger.

Mobius, P. J. (1879): Ueber die Hereditaren Nervenkrankheiten, Samml. klin. Vortr., 171, 1505.

Morrow, R. S., and CoHEN, J. (1954): The Psychosocial Factors in Muscular Dystrophy, J. Child Psychiat. (N.Y.), 3, 70.

Pearce, J. M. S., Pennington, R. J., and Walton, J. N. (1964): Serum Enzyme Studies in Muscle Disease. Part III Serum Creatine Kinase Activity in Relatives of Patients with the Duchenne Type of Muscular Dystrophy, J. Neurol. Neurosurg. Psychiat., 27, 181 .

Pearson, C. M. (1957): Serum Enzymes in Muscular Dystrophy and Certain Other Muscular and Neuromuscular Diseases. I. Serum G.O.T., New Engl. J. Med., 256, 1069.

Pearson, C. M. (1962): Histopatholgical Features of Muscle in the Preclinical Stages of Muscular Dystrophy, Brain, 85, 109.

Pearson, C. M., Fowler, W. M., and Wright, S. W. (1963): X-chromosomal Mosaicism in Females with Muscular Dystrophy, Proc. nat. Acad. Sci. (W ash.), 50, 24.

RichaRDSON, A. T. (1964): Clinical Electromyography. In "Disorders of Voluntary Muscle", p. 536, edit. J. N. Walton, London: J. \& A. Churchill.

Ross, J. (1883): On a Case of Pseudo-hypertrophic Paralysis, Brit. med. J., 1, 200.

SCHAPIRA, G., DREYFUS, J. C., and SChAPIRA, F. (1953): L'élévation du Taux de l'aldolase Serique, Test Biochimique des Myopathies, Sem. Hop. Paris, 29, 1917.

Schapira, F., Dreyfus, J. C., Schapira, G., and Demos, J. (1960): Etude de l'Aldolase et de la Créatine Kinase du Sérum chez les Mères de Myopathes, Rev. franc. Etud. clin. biol., 5, 990.

SCHMIDT, C. C. (1839): Krankhafte Hypertrophie des Muskelsystems, Jahrb. der in-und Aüslandischen ges. Med., 24, 176.

Shy, G. M., and Magee, K. R. (1956): A New Congenital Non-progressive Myopathy, Brain, 79. 610.

SHY, G. M., and McEAcherN, D. (1951): Further Studies of Effects of Cortisone and A.C.T.H. on Neurological Disorders, Brain, 74, 354.

Sjovall, B. (1936): Dystrophia Musculorum Progressiva. Eine Erblichkeits Medizinische und Klinische Studie, Acta psychiat. scand. Suppl., 10. Spencer, G. E., and Vignos, P. J. (1962): Bracing 
for Ambulation in Childhood Progressive Muscular Dystrophy, J. Bone Jt Surg., 44A, 234.

STEINERT, H. (1909): Myopathologische Beiträge: 1 Ueber das Klinische und Anatomische Bild des Muskelschwunds der Myotoniker, Dtsch. Z. Nervenheilk, 37, 58.

STEVENSON, A. C. (1953): Muscular Dystrophy in Northern Ireland, Ann. Eugen. (Lond.), 18, 50.

THOMASEN, E. (1948): Myotonia. Thomsen's Disease (Myotonia congenita), Paramyotonia and Dystrophia Myotonica. Aarhus: Universteits forlaget.

THOMSEN, J. (1876): Tonische Krämpfe in Willkürlich Beweglichen Muskeln in Folge von Ererbterpsychischer Disposition (Ataxia Muscularis?), Arch. Psychiat. Nervenkr., 6, 706.

Thomson, W. H. S., LeybuRN, P., and Walton, J. N. (1960): Serum Enzyme Activity in Muscular Dystrophy, Brit. med. J., ii, 1276.

TYLER, F. H., and WINTROBE, M. M. (1950): Studies in Disorders of Muscle. I. The Problem of Progressive Muscular Dystrophy, Ann. intern. Med., 32, 72.

VAN DEN BosCH, J. (1963): Investigations of the Carrier State in the Duchenne Type Dystrophy, in "Research in Muscular Dystrophy", p. 23, London: Pitman.

Vignos, P. J., and ARChibald, K. C. (1960): Maintenance of Ambulation in Childhood Muscular Dystrophy, J. chron. Dis., 12, 273.

WALTON, J. N. (1955): On the Inheritance of Muscular Dystrophy, Ann. hum. Genet., 20, 1.

WALTON, J. N. (1964a): Progressive Muscular Dystrophy. In "Disorders of Voluntary Muscle," p. 276, edit. J. N. Walton, London: J. \& A. Churchill.
Walton, J. N. (1964b): Muscular Dystrophy: Some Recent Advances in Knowledge, Brit. med. J., i, ̋ 1344.

Walton, J. N., and Adams, R. D. (1958): Poly-市 myositis, Edinburgh: E. \& S. Livingstone.

Walton, J. N., and Natrass, F. J. (1954): On the Classification, Natural History and Treatment of the Myopathies, Brain, 77, 169.

Walton, J. N., and Warrick, C. K. (1954): Osseous? Changes in Myopathy, Brit. J. Radiol., 27, 1.

WARING, J. J., RAVIN, A., and WALKeR, C. E. (1940): Studies in Dystrophia Myotonia. II. Clinical ${ }^{\mathbb{D}}$ Features and Treatment, Arch. intern. Med., 65, को 763.

WEIrZ, W. (1921): Ein Schlussvort zur Frage des $\vec{O}$ Erbganges der Dystrophia Musc-Progr, Dtsch. Z.Nervenheilk, 107, 316.

WELANDER, L. (1951): Myopathia Distalis Tarda Hereditaria; 249 Examined Cases in 72 Pedigrees Act. med. scand., 141, Suppl., 265, 41 .

WELANDER, L. (1957): Homozygous Appearance of Distal Myopathy, Acta Genet. med. (Roma), $7, \overrightarrow{-}$ 321.

Wohlfart, G., Fex, J., and Eliasson, S. (1955): के Hereditary Proximal Spinal Muscular Atrophy- w a Clinical Entity Simulating Progressive Muscular N Dystrophy, Acta psychiat. (Kbh.), 30, 395.

Wolf, A. (1936): Quinine: An Effective Form of Treatment for Myotonia, Arch. Neurol. Psychiat. (Chic.), 36, 382.

WORDEN, D. K., and VIGNOS, P. J. (1962): Intellectual ${ }^{\Phi}$ Function in Childhood Progressive Muscular $\overrightarrow{8}$ Dystrophy, Pediatrics., 29, 968. 